\title{
PERBAIKAN ATAS HUKUM ACARA PENILAIAN UNSUR PENYALAHGUNAAN WEWENANG
}

\author{
Muchamad Arif Agung Nugroho \\ Fakultas Hukum Universitas Wahid Hasyim Semarang \\ agungnugroho@unwahas.ac.id
}

\begin{abstract}
Abstrak
Pasal 21 UU 30/2014 mengatur tentang kewenangan PTUN untuk menilai ada atau tidak adanya unsur penyelahgunaan wewenang yang dilakukan oleh pejabat pemerintah. MA mengeluarkan Perma 4/2015 sebagai pedoman beracara dalam penilaian unsur penyalahgunaan wewenang. Perma 4/2015 memiliki kekurangan atau kelemahan dan tulisan ini bermaksud untuk menggali dan menemukan kekurangan-kekurangan dan kelemahan-kelemahannya supaya dapat dilakukan perbaikan. Tulisan ini menggunakan metode penelitian yuridis normatif, yaitu mengumpulkan data primer lalu data sekunder, selanjutnya data tersebut dibaca, dibandingkan, dan dicari kekurangan atau kelemahan dari Perma 4/2015, berikutnya dianalisis dan diuraikan dalam tulisan ini secara deduktif. Pokok permasalahan dalam penelitian ini ada dua, yaitu 1) apa saja kelemahan hukum acara penilaian unsur penyalahgunaan wewenang? 2) langkah apa saja yang diperlukan negara dalam memperbaiki hukum acara penilaian unsur penyalahgunaan wewenang? Hasil penelitian yang ditemukan adalah ada tiga kelemahan hukum acara penilaian unsur penyalahgunaan wewenang, yaitu istilah permohonan sebaiknya diganti dengan gugatan serta para pihak dalam perkara perlu ditambah yaitu aparat pengawasan intern pemerintah sebagai termohon/tergugat dan juga rakyat (perorangan atau kelompok) sebagai pihak ketiga/interven. Maka dari itu, UU 30/2014 dan Perma 4/2015 harus dirubah untuk menyesuaikan perbaikan tersebut.
\end{abstract}

Kata kunci : Hukum Acara Peradilan Tata Usaha Negara, penyalahgunaan wewenang, menyalahgunakan wewenang, administrasi pemerintahan

\section{A. Pendahuluan}

Kelahiran UU 30/2014 ${ }^{88}$ merupakan babak baru dalam ilmu pengetahuan hukum khususnya ilmu hukum administrai negara, atau yang biasa dikenal dengan HAN. Hukum administrasi negara yang dikenal di Indonesia, selama ini

${ }^{88}$ Undang-undang Nomor 30 Tahun 2014 tentang Administrasi Pemerintahan 
dipandang susah untuk dikodifikasikan karena ilmu hukum administrasi negara itu sendiri menarik dari hukum yang khusus ke hukum yang umum alias bersifat induktif. ${ }^{89}$ Walaupun UU 30/2014 bukan merupakan suatu kitab undang-undang atau kodifikasi hukum namun undang-undang tersebut menjadi pedoman hukum atau payung hukum secara umum terhadap hukum-hukum admininistrai yang khusus. Di massa yang akan datang, semuat aturan-aturan tentang hukum administrasi negara dan juga yang mengatur kebijakan hukum tidak boleh bertentangan dengan undang-undang tersebut. Dengan demikian, UU 30/2014 bukan merupakan suatu kitab hukum atau kodifikasi hukum namun sifat-sifat pengaturannya seperti kitab hukum atau kodifikasi hukum.

Hal yang menarik dari UU 30/2014 adalah adanya aturan tentang kewenangan PTUN ${ }^{90}$ untuk menilai ada atau tidak adanya unsur penyelahgunaan wewenang yang dilakukan oleh pejabat pemerintah. Padahal kalau dikaitkan dengan peraturan perundang-undangan tentang pemberantasan tindak pidana korupsi $^{91}$ maka penyalahgunaan wewenang menjadi salah satu unsur tindak pidana korupsi, seperti Pasal 3 UU 31/99 $9^{92}$ yang berbunyi

\section{Pasal 3}

Setiap orang yang dengan tujuan menguntungkan diri sendiri atau orang lain atau suatu korporasi, menyalahgunakan kewenangan, kesempatan atau sarana yang ada padanya karena jabatan atau kedudukan yang dapat merugikan keuangan negara atau perekonomian negara, dipidana dengan pidana penjara seumur hidup atau pidana penjara paling singkat 1 (satu) tahun dan paling lama 20 (dua puluh) tahun dan atau denda paling sedikit Rp50.000.000,00 (lima puluh juta rupiah) dan paling banyak Rp1.000.000.000,00 (satu milyar rupiah)

Dengan demikian, maka adanya kewenangan PTUN untuk menilai ada atau tidak adanya unsur penyelahgunaan wewenang yang dilakukan oleh pejabat

${ }^{89}$ Ridwan H. R., 2016, Hukum Administrasi Negara, Jakarta: Rajawali Press, Hal 12

${ }^{90}$ Pengadilan Tata Usaha Negara

${ }^{91}$ Abdul Latif, 2018, Hukum Administrasi dalam Praktik Tindak Pidana Korupsi, Jakarta: Prenada Media Grup, Hal 7

${ }^{92}$ Undang-undang Nomor 31 Tahun 1999 tentang Pemberantasan Tindak Pidana Korupsi 
pemerintah dikhawatirkan para terduga korupsi ${ }^{93}$ menjadikan kewenangan PTUN tersebut sebagai salah satu celah untuk lolos dari jeratan pasal tindak pidana korupsi. ${ }^{94}$ Walaupun Mahkamah Agung sudah mengeluarkan Perma 4/2015 guna memenuhi kekosongan hukum acara kewenangan tersebut, namun ada baiknya peraturan tersebut dikaji agar kelemahan-kelemahannya bisa segera ditemukan dan diperbaiki.

Pasal 21 UU 30/2014 mengatur tentang kewenangan PTUN untuk menilai ada atau tidak adanya unsur penyelahgunaan wewenang yang dilakukan oleh pejabat pemerintah. Ini adalah kewenangan baru bagi PTUN. Sebagai lembaga peradilan, PTUN tentu membutuhkan seperangkat aturan beracara dalam melaksanakan kewenangan itu. Melihat situasi demikian, $\mathrm{MA}^{96}$ mengatasinya dengan mengeluarkan Perma 4/2015 sebagai pedoman beracara dalam penilaian unsur penyalahgunaan wewenang.

Sebagai suatu hukum tertulis apalagi baru, Perma 4/2015 pasti memiliki kekurangan atau kelemahan. Maka dari itu, tulisan ini bermaksud untuk menggali dan menemukan kekurangan-kekurangan dan kelemahan-kelemahan Perma 4/2015, supaya ke depannya nanti dapat dilakukan perbaikan.

Tulisan ini menggunakan metode penelitian yuridis normatif. Diawali dengan mengumpulkan data primer, yaitu hukum-hukum yang tertulis seperti UU 30/2014 dan Perma 4/2015. Lalu, dilanjutkan dengan mengumpulkan data-data sekunder, seperti literatur-literatur tentang hukum acara khususnya buku-buku tentang Hukum Acara Peradilan Tata Usaha Negara. Setelah data-data tersebut

93 Philipus M. Hadjon, dkk, 2016, Hukum Administrasi dan Tindak Pidana Korupsi, Yogyakarta: Gadjah Mada University Press, Hal 45

94 Disiplin F. Manao, 2017, Penyalahgunaan Wewenang pada Tindak Pidana Korupsi dalam Perspektif Hukum Administrasi Negara, Jakarta: CV. Kreasi Sahabat Bersama, Hal 26

${ }^{95}$ Peraturan Mahkamah Agung Nomor 4 Tahun 2015 Tentang Pedoman Beracara dalam Penilaian Unsur Penyalahgunaan Wewenang

${ }^{96}$ Mahkamah Agung 
dikumpulkan, langkah selanjutnya adalah dibaca, dibandingkan, lalu dicari kekurangan-kekurangan dan kelemahan-kelemahannya. Yang terakhir adalah dianalisis dan diuraikan dalam tulisan ini secara deduktif.

Adapun pokok permasalahan dalam penelitian ini adalah

1. Apa saja kelemahan hukum acara penilaian unsur penyalahgunaan wewenang?

2. Langkah apa saja yang diperlukan negara dalam memperbaiki hukum acara penilaian unsur penyalahgunaan wewenang?

\section{B. Metode Penelitian}

Tulisan ini menggunakan metode penelitian yuridis normatif ${ }^{97}$. Diawali dengan mengumpulkan data primer, yaitu hukum-hukum yang tertulis seperti UU 30/2014 dan Perma 4/2015. Lalu, dilanjutkan dengan mengumpulkan data-data sekunder, seperti literatur-literatur tentang hukum acara khususnya buku-buku tentang Hukum Acara Peradilan Tata Usaha Negara. Setelah data-data tersebut dikumpulkan, langkah selanjutnya adalah dibaca, dibandingkan, lalu dicari kekurangan-kekurangan dan kelemahan-kelemahannya. Yang terakhir adalah dianalisis dan diuraikan dalam tulisan ini secara deduktif.

Penelitian bersifat yuridis normatif. Penulis mempelajari terlebih dahulu peraturan-peraturan perundang-undangan yang berkaitan atau mengatur tentang:

a. hukum acara peradilan tata usaha negara, dan

b. penyalahgunaan wewenang.

Peraturan-peraturan perundang-undangan yang dimaksud antara lain adalah

a. Undang-undang Nomor 5 Tahun 1986 tentang Peradilan Tata Usaha Negara,

b. Undang-undang Nomor 9 Tahun 2004 tentang Perubahan atas Undangundang Nomor 5 Tahun 1986 Tentang Peradilan Tata Usaha Negara,

c. Undang-undang Nomor 51 Tahun 2009 Tentang Perubahan Kedua atas Undang-undang Nomor 5 Tahun 1986 Tentang Peradilan Tata Usaha Negara,

${ }^{97}$ Zainudin Ali, 2017, Metode Penelitian Hukum, Jakarta: Sinar Grafika, Hal 11 
d. Undang-undang Nomor 30 Tahun 2014 Tentang Administrasi Pemerintahan, dan

e. Peraturan Mahkamah Agung Nomor 4 Tahun 2015 Tentang Pedoman Beracara dalam Penilaian Unsur Penyalahgunaan Wewenang.

Penelitian terhadap peraturan-peraturan perundang-undangan tersebut dilakukan dengan cara:

a. dibaca,

b. dipahami,

c. dibandingkan satu sama lain,

d. dicari kelemahan atau kekurangannya,

e. dicari solusi atas kelemahan atau kekurangannya, dan yang terakhir

f. diuraikan dalam bentuk tulisan ini.

\section{Pembahasan}

\section{Kelemahan Hukum Acara Penilaian Unsur Penyalahgunaan Wewenang}

Pasal 21 UU 30/2014 mengatur tentang kewenangan PTUN untuk menilai ada atau tidak adanya unsur penyelahgunaan wewenang yang dilakukan oleh pejabat pemerintah. Ini adalah kewenangan baru bagi PTUN. Sebagai lembaga peradilan, PTUN tentu membutuhkan seperangkat aturan beracara dalam melaksanakan kewenangan itu. ${ }^{98}$ Melihat situasi demikian, MA $^{99}$ mengatasinya dengan mengeluarkan Perma 4/2015 sebagai pedoman beracara dalam penilaian unsur penyalahgunaan wewenang.

Sebagai suatu hukum tertulis apalagi baru, Perma 4/2015 pasti memiliki kekurangan atau kelemahan. Maka dari itu, tulisan ini bermaksud untuk menggali dan menemukan kekurangan-kekurangan dan kelemahan-kelemahan Perma 4/2015, supaya ke depannya nanti dapat dilakukan perbaikan.

98 M. Ikbar Andi Endang, 2017, Rasio Hukum Pengujian Penyalahgunaan Wewenang Berdasarkan Undang-Undang Administrasi Pemerintahan, Lampung: Aura Publishing, Hal 70

${ }^{99}$ Mahkamah Agung 
Ada 3 hal kelemahan yang disorot dalam pedoman beracara dalam penilaian unsur penyalahgunaan wewenang, yaitu a) permohonan, b) para pihak, c) putusan, sebagai berikut pembahasaannya:

\section{a) Permohonan}

Penyalahgunaan wewenang yang diatur dalam UU 30/2014 termasuk kajian $\mathrm{HAN}^{100}$ sehingga hukumnya bersifat publik. Namun demikian, hukum fomil dari HAN bersifat privat, karena menyerahkan sepenuhnya inisiatif penegakan hukum materiilnya kepada pihak yang merasa dirugikan, sebagaimana sudah dipraktikkan dalam hukum acara PTUN sejak lama. ${ }^{101}$ Sehingga, pencari keadilan yang akan berperkara di PTUN haruslah mengajukan gugatan terlebih dahulu, dan bukan mengajukan permohonan.

Karena hukum acaranya bersifat privat, maka hukum acaranya mirip sekali dengan hukum acara perdata. Oleh karena itu, hukum acara perdata sangat relevan untuk dimanfaatkan untuk mengkaji kelemahan hukum acara dalam penilaian unsur penyalahgunaan wewenang.

Penggunaan istilah permohonan dalam beracara dalam penilaian unsur penyalahgunaan wewenang adalah tidak tepat, karena pada dasarnya penilaian unsur penyalahgunaan wewenang memiliki kandungan sengketa, sehingga lebih tepat menggunakan istilah gugatan. Dengan menggunakan gugatan, maka ada pihak tergugat yang harus diberi kesempatan untuk menanggapinya. Oleh karena itu, kelemahan pertama yang ditemukan adalah perlu diadakan penambahan satu pihak, yaitu pihak tergugat.

Beracara dalam penilaian unsur penyalahgunaan wewenang akan lebih tepat jika dimulai dengan mengajukan gugatan, bukan mengajukan permohonan, sebagaimana mengikuti hukum acara PTUN selama ini yang menggunakan gugatan. Ditambah lagi, penilaian unsur penyalahgunaan wewenang memiliki

\footnotetext{
${ }^{100}$ Hukum Administrasi Negara

${ }^{101}$ R. Wiyono, 2018, Hukum Acara Peradilan Tata Usaha Negara, Jakarta: Sinar Grafika, Hal 55
} 
kandungan sengketa di dalamnya, yang mana ada pejabat/badan pemerintah yang tidak terima atas hasil pengawasan aparat pengawasan intern pemerintah.

Dalam undang-undang tidak dijelaskan pengertian hasil itu dalam bentuk apa, tetapi kalau melihat kelaziman dalam praktik berpemerintahan, tentu bentuk dari hasil itu adalah suatu keputusan tertulis (beschikking). Artinya, kalau memang objek sengketa dalam HAPUPW ${ }^{102}$ itu adalah suatu keputusan dalam artian beschikking, maka sengketa penilaian unsur penyalahgunaan wewenang tidaklah berbeda dengan hukum acara PTUN. ${ }^{103}$

\section{b) Para Pihak}

Hanya satu pihak dalam beracara penilaian unsur penyalahgunaan wewenang, yaitu pemohon. Kalau memang cukup satu pihak saja, maka seharusnya produk yang dihasilkan oleh hakim setelah mengadili adalah penetapan, bukan putusan. Tetapi, pada kenyataannya, produk yang dihasilkan adalah putusan.

Sebagaimana dijelaskan sebelumnya, perkara penilaian unsur penyalahgunaan wewenang sebenarnya perkara yang mengandung sengketa, sehingga lebih tepat jika pengajuan perkaranya berdasarkan gugatan. Kalau toh, memang sudah diatur harus berdasarkan permohonan, maka setidaknya dibukalah kesempatan bagi pihak termohon.

Perlu diingat, salah satu asas hukum acara adalah "hakim mendengar kedua belah pihak". Artinya, pihak lawan, yaitu aparat pengawasan intern pemerintah, diberi kesempatan untuk menanggapi permohonan/gugatan, sehingga kedudukannya dijadikan sebagai termohon/tergugat. Dengan demikian, hakim bisa menilai secara berimbang dan objektif.

Selain perlunya termohon/tergugat dimasukkan dalam perkara, pihak ketiga yang merasa berkepentingan, seyogyanya diberi kesempatan juga untuk masuk dalam perkara. Yang namanya badan/pejabat pemerintah, diberi wewenang

\footnotetext{
102 Hukum Acara Penilaian Unsur Penyalahgunaan Wewenang

103 Zairin Harahap, 2018, Hukum Acara Peradilan Tata Usaha Negara, Jakarta: Rajawali Press, Hal 22
} 
tentu tujuan utamanya adalah untuk melayani rakyat. Nah, apabila ternyata dalam melaksanakan wewenang tersebut dinyatakan ada unsur penyalahgunaan, lalu diuji oleh PTUN, maka rakyat, perlu diberi kesempatan untuk masuk dalam perkara dalam rangka membela kepentingannya. Rakyat ini bisa diartikan perseorangan atau kelompok dalam bentuk LSM $^{104}$ atau organisasi kemasyarakatan.

\section{c) Putusan}

Penggunaan istilah putusan sudah tepat, jika pihak lain (termohon/tergugat) diberi kesempatan untuk masuk ke dalam perkara. Akan tetapi, istilah putusan menjadi tidak tepat jika pihak lain tidak ada, sehingga HAPUPW akan lebih tepat bila menggunakan istilah penetapan. Karena, dengan tidak dimasukannya pihak lain, maka perkara tersebut dipandang tidak memiliki kandungan sengketa, sehingga lebih tepat apabila menggunakan istilah penetapan.

Akan tetapi, jika istilah penetapan tetap dipakai maka akan semakin tidak tepat, karena salah satu amarnya bersifat kondemnatoir, lihat Pasal 17 huruf b, yaitu “..... Memerintahkan kepada negara untuk mengembalikan kepada pemohon uang yang telah dibayar." Sehinga, sebagaimana dikatakan pada paragraf awal, pada dasarnya penggunaan istilah putusan sudahlah tepat, karena memang salah satu isi amarnya bersifat kondemnatoir.

Amar putusan yang bersifat kondemnatoir itu akan lebih pas jika aparat pengawasan intern pemerintahan dimasukkan sebagai tergugat/termohon, agar dirinya bisa melakukan tanggapan/bantahan atas permohonan yang diajukan pihak pemohon. Sehingga putusan akan menjadi objektif dan memenuhi rasa keadilan. Kalau toh nanti pihak termohon kalah dan dihukum berdasarkan putusan, setidaknya pihak termohon memiliki keyakinan argumentatif bahwa kekalahannya itu sudah adil, karena dilalui dengan proses peradilan yang objektif.

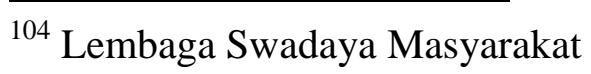




\section{Langkah Negara dalam Memperbaiki Hukum Acara Penilaian Unsur Penyalahgunaan Wewenang}

Setelah diungkap kelemahan-kelemahan dan kekurangan-kekurangan HAPUPW dalam uraian di atas, maka langkah-langkah yang perlu diambil oleh negara adalah melakukan perubahan terhadap peraturan perundang-undangan, khususnya UU 30/2014 dan Perma 4/2015.

Pertama, UU 30/2014 dirubah dulu, yaitu kata-kata permohonan dalam Pasal 21 dirubah menjadi gugatan. Kalau toh, melakukan perubahan terhadap undang-undang itu prosesnya lama dan tidak mudah, maka Pasal 21 UU 30/2014 bisa saja tidak perlu dirubah, akan tetapi Perma 4/2015 harus dirubah, karena merubah Perma lebih mudah prosesnya daripada merubah UU. Merubah Perma cukup dilakukan oleh satu lembaga saja yaitu Mahkamah Agung, sedangkan untuk merubah UU memerlukan dua lembaga yaitu DPR dan Presiden, walaupun Presiden bisa saja mengeluarkan Perpu, namun untuk mengeluarkan Perpu harus ada kegentingan yang memaksa. Padalah perubahan terhadap UU 30/2014 tidak ada kejadian yang dianggap genting/memaksa.

Jadi simpulan dari langkah pertama adalah UU 30/2014 dirubah dulu, yaitu kata-kata permohonan dalam Pasal 21 dirubah menjadi gugatan. Melakukan perubahan terhadap undang-undang itu prosesnya lama dan tidak mudah, maka Pasal 21 UU 30/2014 bisa saja tidak perlu dirubah, akan tetapi Perma 4/2015 harus dirubah, karena merubah Perma lebih mudah prosesnya daripada merubah UU. Merubah Perma cukup dilakukan oleh satu lembaga saja yaitu Mahkamah Agung, sedangkan untuk merubah UU memerlukan dua lembaga yaitu DPR dan Presiden, walaupun Presiden bisa saja mengeluarkan Perpu, namun untuk mengeluarkan Perpu harus ada kegentingan yang memaksa. Padalah perubahan terhadap UU 30/2014 tidak ada kejadian yang dianggap genting/memaksa.

Kedua, Perma 4/2015 harus dirubah oleh Mahkamah Agung. Kata-kata permohonan dan pemohon diubah menjadi gugatan dan penggugat. Tetapi, kembali lagi, perubahan tersebut hanya bisa dilakukan jika kata-kata permohonan dalam UU 30/2014 juga dirubah menjadi gugatan, jika tidak, maka istilah permohonan dan pemohon dalam Perma 4/2014 tetap dipertahankan, cuma perlu 
ditambahi masuknya pihak lain, yaitu aparat pengawasan intern pemerintah sebagai termohon dan rakyat (perorangan atau kelompok) sebagai pihak ketiga/interven.

Jadi simpulan langkah kedua adalah Perma 4/2015 harus dirubah oleh Mahkamah Agung. Kata-kata permohonan dan pemohon diubah menjadi gugatan dan penggugat. Tetapi, kembali lagi, perubahan tersebut hanya bisa dilakukan jika kata-kata permohonan dalam UU 30/2014 juga dirubah menjadi gugatan, jika tidak, maka istilah permohonan dan pemohon dalam Perma 4/2014 tetap dipertahankan, cuma perlu ditambahi masuknya pihak lain, yaitu aparat pengawasan intern pemerintah sebagai termohon dan rakyat (perorangan atau kelompok) sebagai pihak ketiga/interven.

\section{Simpulan}

1. Ada tiga sorotan yang menjadi kelemahan hukum acara penilaian unsur penyalahgunaan wewenang, yaitu permohonan, para pihak, putusan. Permohonan lebih tepat diganti dengan gugatan, karena perkaranya bersifat sengketa dan sangat dimungkinkan masuknya pihak ketiga. Para pihak perlu ditambah lagi, yaitu aparat pengawasan intern pemerintah sebagai termohon/tergugat dan juga rakyat (perorangan atau kelompok) sebagai pihak ketiga/interven, maka dengan demikian keseimbangan dalam kepentingan terjadi, mengingat penyalahgunaan wewenang tidak hanya masalah hukum administrasi negara saja namun juga menyangkut ketentuan peraturanperaturan pemberantasan korupsi. Sedangkan penggunaan istilah putusan sudah tepat, karena memang amarnya memiliki kandungan sifat kondemnatoir.

2. Langkah pertama dalam memperbaiki HAPUPW adalah dengan cara merubah kata permohonan dalam UU 30/2014 menjadi gugatan. Perubahan ini memang sulit karena perubahan atas undang-undang harus melibatkan dua lembaga tinggi negara, yaitu DPR RI dan Presiden. Namun demikian, kita harus optimis demi kemajuan bangsa. Perubahan atas undan-undang akan menjadi mudah kalau memang ada kesungguhan dari semua pihak yang ini 
hukum di Indonesia semakin baik. Selanjutnya merubah Perma 4/2015, yaitu kata permohonan diganti menjadi gugatan. Jika istilah permohonan dalam UU 30/2014 tetap dipertahankan, maka istilah permohonan dalam Perma 4/2015 tidak perlu dirubah. Lalu, para pihak ditambah lagi, yaitu pihak termohon/tergugat dan pihak ketiga/interven. Sedangkan istilah putusan masih tetap dipertahankan. Berbeda dengan merubah undang-undang, perubahan Perma lebih mudah karena hanya melibat satu lembaga tinggi negara yaitu MA. 


\section{Daftar Pustaka}

Abdul Latif, 2018, Hukum Administrasi dalam Praktik Tindak Pidana Korupsi, Jakarta: Prenada Media Grup

Disiplin F. Manao, 2017, Penyalahgunaan Wewenang pada Tindak Pidana Korupsi dalam Perspektif Hukum Administrasi Negara, Jakarta:

CV. Kreasi Sahabat Bersama

M. Ikbar Andi Endang, 2017, Rasio Hukum Pengujian Penyalahgunaan Wewenang Berdasarkan Undang-Undang Administrasi Pemerintahan, Lampung: Aura Publishing

Philipus M. Hadjon, dkk, 2016, Hukum Administrasi dan Tindak Pidana Korupsi, Yogyakarta: Gadjah Mada University Press

Ridwan H. R., 2016, Hukum Administrasi Negara, Jakarta: Rajawali Press

R. Wiyono, 2018, Hukum Acara Peradilan Tata Usaha Negara, Jakarta: Sinar Grafika

Zainudin Ali, 2017, Metode Penelitian Hukum, Jakarta: Sinar Grafika

Zairin Harahap, 2018, Hukum Acara Peradilan Tata Usaha Negara, Jakarta: Rajawali Press 